Goldschmidt 2021 Abstract

https://doi.org/10.7185/gold2021.6237

\section{Geochemical behaviour of Rare Earth Elements (REE) and other trace elements in a former Uranium Mine}

$$
\begin{aligned}
& \text { ANDRES ANIBAL CARDENAS NIÑO SR. }{ }^{1}, \text { ROSA } \\
& \text { MARQUES }{ }^{2}, \text { MARIA ISABEL DIAS }{ }^{3}, \text { CATARINA }^{4} \text {. } \\
& \text { DIAMANTINO }{ }^{4} \text { AND EDGAR CARVALHO }{ }^{4}
\end{aligned}
$$

${ }^{1}$ Instituto Superior Técnico

${ }^{2}$ Centro de Ciências e Tecnologias Nucleares (C2TN), Instituto Superior Técnico, Universidade de Lisboa

${ }^{3}$ IST / University of Lisbon

${ }^{4}$ EDM - Empresa de Desenvolvimento Mineiro

Presenting Author: andres.nino@ctn.tecnico.ulisboa.pt

Rare earth elements (REE) are crucial for manufacturing a broad array of high-tech products, devices, and technologies with widespread application in the medical, aerospace, and automobile industries[1]. Due to the huge demand for the REE in the world, the European Union decided to develop ambitious training projects such as PANORAMA. This project will intent to investigate REE environmental behaviour, the fine REE speciation at a molecular level in solution, suspension, contaminated solids, and living organisms.[2]. In the framework of the PANORAMA project a $\mathrm{PhD}$ program is ongoing by the first author, including the study of an old uranium mine (Quinta do Bispo mine) in the centre of Portugal (figure 1) aiming to quantify and study the behaviour of REE and other trace elements in surrounding water-stream sediment and soil systems. In this work the major goal is present first results of the study of REE behaviour in uranium-rich environments, and its relationship with the chemical composition of water, soil and stream sediments, using as case study the Quinta do Obispo uranium mine through the study and modelling of their interaction with the whole system.

During November 2020, the first fieldwork campaign was performed to collect some water, soil and stream sediments samples in contaminated and non-contaminated contexts of Quinta do Bispo mine. Key parameters such as: $\mathrm{pH}, \mathrm{EC}$, TDS were measured in the field. The mineralogical composition of soils and stream samples were achieved by means of X-ray diffraction (XRD). REE and trace elements were determined by inductively coupled plasma mass spectroscopy (ICP-MS) in soils and stream samples.

Results point to contrasting REE concentrations and patterns were observed in water samples regarding the prevailing environmental conditions. In addition, the interactions of REEsurface interactions with the clay minerals, and other nanoparticles, contributes for a better characterization of REE mobility in uranium rich contexts

[1] Dutta, T., Kim, K.-H., Uchimiya, M., Jeon, B.-H., Deep, A., Yun, S.-T., \& Kwon, E. (2016). Global demand for rare earth resources and strategies for green mining. Environmental Research, 182-190.

[2] Université de Rennes 1. (2020). Panorama H2020International Training Networks. Retrieved from What is PANORAMA: https://itn-panorama-h2020.univ-rennes1.fr/what- panorama

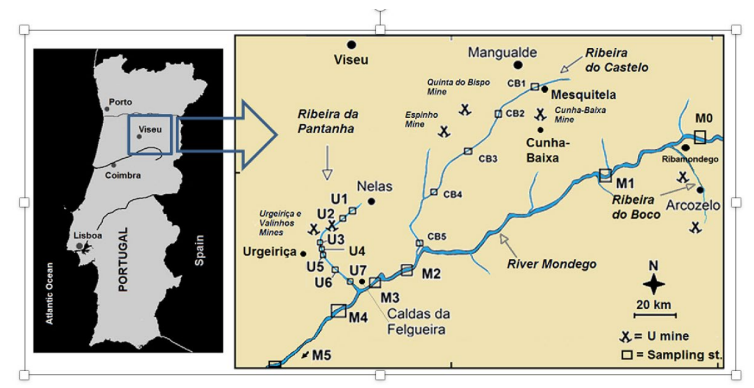

